\title{
Forage intake and botanical composition of feed for cattle fed Brachiaria/egume mixtures
}

\author{
Robert Macedo ${ }^{1}$; Ricardo Martinez Tarré2 ${ }^{2}$ Elvino Ferreira²; Claudia de Paula Rezende ${ }^{3}$; \\ José Marques Pereira ${ }^{3}$; Georg Cadisch ${ }^{4}$; Janaina Ribeiro Costa Rouws; ; Bruno José \\ Rodrigues Alves ${ }^{5}$ Segundo Urquiaga ${ }^{5}$; Robert Michael Boddey ${ }^{5 *}$ \\ ${ }^{1}$ Embrapa Arroz e Feijão/Núcleo de Gado de Leite, Rod. Goiânia-Nova Veneza, km 12 - 75375-000 - Santo \\ Antônio de Goiás, Goiás - Brasil. \\ ${ }^{2}$ UFRuralRJ - Depto. de Solos - 23890-000 - Seropédica, RJ - Brasil. \\ ${ }^{3}$ CEPLAC/Estação de Zootecnia do Extremo Sul da Babia (ESSUL), BR 101, km 757, Itabela, BA - Brasil. \\ ${ }^{4}$ University of Hohenheim/Institute of Plant Production and Agroecologie in the Tropics and Subtropics - \\ 70593 - Stuttgart - Germany. \\ 'Embrapa Agrobiologia, C.P. 74505 - 23890-000 - Seropédica, RJ - Brasil. \\ *Corresponding author <bob@cnpab.embrapa.br>
}

ABSTRACT: A key contribution to study the cycling of nutrients in soil/plant/animal systems is the evaluation of the consumption of forage and their nutrients by cattle. The objective of this study was to test techniques to evaluate faecal production, in vitro digestibility, forage consumption and the proportion of legume in the acquired diet. Five Zebu steer calves were confined and fed five diets of different combinations of Brachiaria dictyoneura and Desmodium ovalifolium. All quantities of faeces were collected per animal and these values were found to compare favourably with those derived from using the chromium oxide technique. In vitro digestibility ranged from 7 to $10 \%$ higher than the actual in vivo digestibility. Faecal samples from steers fed with diets with $25 \%$ or more of grass in the mixture were found to be depleted in $\delta^{13} \mathrm{C}$ between 1.7 and $2.1 \%$, but no depletion was observed when the diet was $100 \% \mathrm{D}$. ovalifolium. There was a positive linear regression $\left(\mathrm{r}^{2}=0.97^{*} \%\right)$ of the $\delta^{13} \mathrm{C}$ of the diet with the $\delta^{13} \mathrm{C}$ of faeces, but if the acquired diet contained a very high proportion of legume, the legume content could be underestimated by as much as $10 \%$. None of the internal indicators, such as lignin or ash content of the diets, were useful to predict feed intake, but the chromium oxide external indicator performed satisfactorily. The ${ }^{13} \mathrm{C}$ analysis of the faeces was an effective predictor of the proportion of the legume in the consumed diet.

Key words: Brachiaria dictyoneura, Desmodium ovalifolium, ${ }^{13} \mathrm{C}$ abundance, digestibility, forage intake

\section{Consumo e composição da forragem ingerida por bovinos alimentados com Brachiaria e uma leguminosa}

\begin{abstract}
RESUMO: Uma contribuição fundamental para o estudo da ciclagem de nutrientes no sistema solo/planta/ animal é a avaliação do consumo pelo gado de forragem e dos nutrientes nela contidos. Testaram-se, sob condições controladas, técnicas para avaliar a produção fecal, digestibilidade in vitro, consumo de forragem e a proporção de leguminosa ingerida na dieta. Cinco novilhos de Zebu foram confinados e alimentados com quantidades conhecidas de cinco rações com diferentes proporções de Brachiaria dictyoneura e Desmodium ovalifolium. Todas as fezes bovinas foram recolhidas e pesadas e estes valores foram comparáveis com as estimativas da produção fecal derivadas do uso da técnica de óxido de cromo. A digestibilidade in vitro variou de 7 a 10\% acima da digestibilidade in vivo atual. Amostras de fezes de novilhos alimentados com dietas com $25 \%$ ou mais de capim na mistura apresentaram abundância de ${ }^{13} \mathrm{C}$ por entre 1,7 e 2,1\%o, mas este empobrecimento isotópico não foi observado quando a dieta era com $100 \%$ D. ovalifolium. Houve correlação positiva linear $\left(\mathrm{r}^{2}=0,97 \% * \%\right)$ entre $\delta^{13} \mathrm{C}$ da dieta com o $\delta^{13} \mathrm{C}$ das fezes, mas o conteúdo de leguminosa foi subestimado em mais de $10 \%$ quando a dieta ingerida foi de $100 \%$ de leguminosa. Nenhum dos indicadores internos, como o conteúdo de lignina ou cinzas, foram úteis para prever o consumo de forragem, mas os resultados da técnica utilizando óxido crômico como indicador externo foram satisfatórios. A abundância de ${ }^{13} \mathrm{C}$ das fezes foi indicador adequado da proporção da leguminosa na dieta.

Palavras-chave: Brachiaria dictyoneura, Desmodium ovalifolium, abundância natural de ${ }^{13} \mathrm{C}$, digestibilidade, consumo animal
\end{abstract}

\section{Introduction}

In the tropical region of Brazil sown pastures are dominated by species of Brachiaria. In recent years there has been some success with the introduction of forage legumes to the pasture such as forage groundnut (Arachis pintoi), Desmodium ovalifolium and Stylosanthes spp. to form mixed swards (Valentim et al., 2001; Pereira 
et al., 2005; Embrapa, 2007). The evaluation of forage intake and the botanical composition of the diet is an important objective to determine the efficiency of utilisation of both legume and grass components of the sward by grazing animals. Furthermore, in nutrient cycling studies it is essential to determine the proportion of the total sward dry matter (DM) production consumed by the animals and the total quantities of nutrients consumed and excreted (Russelle, 1997; Boddey et al., 2004).

External markers such as chromium oxide and n-alkanes have been widely used for determining faecal production and the methods compared (e.g. Malossini et al., 1996; Oliveira et al., 2007). Likewise it is a routine to use these techniques in conjunction with estimates of in vitro digestibility (Tilley and Terry, 1963) to determine herbage intake. However, it appears that there are no studies on tropical forages using confined cattle where these techniques were compared with in vivo faecal production and actual herbage consumption.

The objectives of this study using confined cattle were to: i) compare faecal output determined by the chromium oxide method with actual faecal output, ii) investigate the possibility that some internal marker such as fibre, lignin or ash contents of the forage mixtures could be used to determine faecal output, iii) compare in vitro digestibility determined using rumen liquor with that determined from actual in vivo herbage intake and faecal output, and, iv) compare, using the ${ }^{13} \mathrm{C}$ natural faeces abundance (Jones et al., 1979) estimates of the proportion of legume in different legume/grass mixtures with the actual consumption by the confined cattle.

\section{Material and Methods}

This study was conducted in the extreme south of the state of Bahia, Brazil (16 $39^{\circ}$ S, 39०30" W), with mean annual rainfall of $1,400 \mathrm{~mm}$, no marked dry season, and average temperatures ranging from 19 to $29^{\circ} \mathrm{C}$ (for more complete data see Rezende et al., 1999). The experiment was conducted using five Zebu steer calves, housed individually in covered $4 \times 3 \mathrm{~m}$ enclosures with open sides and sawdust litter. Mineral salts and water were supplied in excess following the general practice of the region.

The experimental design consisted of a $5 \times 5$ Latin square with five treatments (diets) and five animals. Each animal received each diet for a period of ten days. The samples of faeces were taken for the last seven days for each diet period, but the comparisons of analyses of internal indicators and chromium were only made on the samples from the last three days of the diet period. Hence the effective time for changeover from one diet to the next was seven days.

Five diets were prepared from legume (Desmodium ovalifolium) and grass (Brachiaria dictyoneura) harvested from the field, processed in a silage chopper and then laid out to dry in the sun to form hay. The diets had the following composition on a dry weight basis: $100 \%$
Brachiaria dictyoneura (cv. CIAT 6133); 75\% B. dictyoneura $+25 \%$ Desmodium ovalifolium (cv. Itabela = CIAT 350); $50 \%$ B. dictyoneura $+50 \%$ D. ovalifolium; $25 \% B$. dictyoneura $+75 \%$ D. ovalifolium, and $100 \% D$. ovalifolium

At the beginning of the experiment the animals were all approximately the same age (21.6 \pm 1.5 months) and weight $(287 \pm 28 \mathrm{~kg})$. Before the experiment, the steers were treated for possible endo and ecto parasites, vaccinated against foot and mouth, brucelosis and hydrophobia diseases. During the study the animals were fitted with faecal collection bags to collect all excreted faeces. It was not possible to collect urine as the animals were too lively. A period of 70 days before the start of the experiment was used to adapt the animals to confinement, experimental diets, and to wearing of the collection bags. At the start and end of the experiment the animals were weighed after $18 \mathrm{~h}$ of fasting, but during the experiment they were weighed every 10 days (at each diet change) without fasting.

The five diets were offered to the respective animals in excess twice a day (morning - 08h00 and afternoon - 15h00) in the feed trough, and the left-over feed was collected before adding the next aliquot of feed. Each feeding period lasted ten days and then the diet was changed in accordance with the randomised Latin square design. The quantity of feed offered to the animals and remnants were weighed and samples taken for dry matter determination $\left(65^{\circ} \mathrm{C}\right.$ for $\left.>72 \mathrm{~h}\right)$. The dried samples for each diet were ground to $<85$ mesh and analysed for acid detergent fibre, lignin, cellulose, ash, total $\mathrm{N}$, in vitro digestibility and ${ }^{13} \mathrm{C}$ abundance as described below.

All faeces excreted by the animals during the last seven days on each diet were collected in the faecal bags. These bags were emptied twice a day (morning/afternoon) into a tared bucket, weighed, homogenised and a sample taken was taken to be dried $\left(65^{\circ} \mathrm{C}>48 \mathrm{~h}\right)$. Samples taken for the each of the seven days were analysed for ${ }^{13} \mathrm{C}$ abundance (Jones et al., 1979), and samples from the last three days of each period for acid detergent fibre, lignin, cellulose, ash, total $\mathrm{N}$, in vitro digestibility.

The direct measurement of animal intake of the different forage mixtures was estimated from the quantities administered each day minus that left in the feeding troughs. To determine faecal production the technique described by Raymond and Minson (1955) was utilised. Confined animals were fed daily (8h00) immediately after the collection of the first faecal sample, with two cartridges each containing $5 \mathrm{~g}$ of powdered $\mathrm{Cr}_{2} \mathrm{O}_{3}$, applied simultaneously via a PVC tube $(19 \mathrm{~mm}$ o.d.) inserted down the throat. The cartridges were hand made by tightly rolling the $5 \mathrm{~g}$ samples of $\mathrm{Cr}_{2} \mathrm{O}_{3}$ in absorbent paper (similar to newspaper). Faecal samples were thereafter taken during the last 3 days of each diet and analysed for chromium content as described below. 


\section{Analytical techniques}

Fibre, lignin and ash determinations - determined using a procedure based on that of Van Soest and Wine (1967). A $1 \mathrm{~g}$ aliquot of each sample of forage or faeces was digested in a solution of acidified ( $0.5 \mathrm{M}$ sulphuric acid) detergent solution for $60 \mathrm{~min}$ after boiling in a $600 \mathrm{~mL}$ beaker as described by Cochran et al. (1986). Subsequently, while the suspension was still hot, the contents were filtered into a weighed borosilicate filter followed by washing twice each using approximately $30 \mathrm{~mL}$ of hot water $\left(\sim 80^{\circ} \mathrm{C}\right)$ as well as acetone (AR grade). The samples were dried at $105^{\circ} \mathrm{C}$ and after cooling in a desiccator, they were reweighed to determine the dry weight of remaining fibre. Finally the lignin was solubilized with acidified $\mathrm{KMnO}_{4}$ solution, and the crucible reweighed to determine the quantity of cellulose in the sample.

In vitro digestibility - $500 \mathrm{mg}$ samples of plant material were placed into test tubes and immersed in 50 $\mathrm{mL}$ buffered rumen liquor taken from a dairy cow fitted with a rumen fistula as described by Tilley and Terry (1963). Tubes were incubated anaerobically under $\mathrm{CO}_{2}$ at $\mathrm{pH} 6.9$ at $39^{\circ} \mathrm{C}$ for $48 \mathrm{~h}$, followed by further $48 \mathrm{~h}$ incubation under acidic aerobic conditions. Finally, samples were filtered under vacuum through a ceramic sintered filter and dried at $105^{\circ} \mathrm{C}$ to constant weight. The in vitro digestibility was calculated from the weight loss during the digestions compared to the weight of the digested sample.

Total N - $200 \mathrm{mg}$ (dry weight) of each sample were analysed for total $\mathrm{N}$ using the semi-micro Kjeldahl digestion technique followed by steam distillation using a Tecator Kjeltec model 3100 (Tecator, Höganäs, Sweden) automatic titration/distillation unit as described by Urquiaga et al. (1992).

${ }^{13} \mathrm{C}$ abundance - Dry samples of forage mixtures and faeces were finely ground using a roller mill similar to that described by Arnold and Schepers (2004). The ${ }^{13} \mathrm{C}$ isotopic abundance of the samples was determined on aliquots containing between 200 and 400 mg total C using a Europa Scientific continuous-flow isotope-ratio mass spectrometer (Model 20-20) coupled to the output of an automated total $\mathrm{C}$ and $\mathrm{N}$ analyser.

Chromium content of faeces - $500 \mathrm{mg}$ of dry faeces were digested for $12 \mathrm{~h}$ in $6 \mathrm{~mL}$ of concentrated nitric acid at $25^{\circ} \mathrm{C}$ in an aluminium heating block. Tubes were then heated for $1 \mathrm{~h}$ to $160^{\circ} \mathrm{C}$, cooled to room temperature, amended with $4 \mathrm{~mL}$ of perchloric acid and then heated for approximately one more hour until the colour of the digest was transparently yellow. These samples, when cool, were diluted to $50 \mathrm{~mL}$ and analysed using the colorimetric method described by Kimura and Miller (1956).

\section{Calculations and statistical analyses}

Calculation of the proportion of legume in the diets - Using the ${ }^{13} \mathrm{C}$ abundance technique, the proportion of $\mathrm{C}$ in the faeces $\left(\% \mathrm{C}_{\mathrm{Leg}}\right)$ derived from the legume can be calculated from the equation (Coates et al., 1987):

$\% \mathrm{C}_{\text {Leg }}=100 \cdot\left(\delta^{13} \mathrm{C}_{\mathrm{G}}-\delta^{13} \mathrm{C}_{\mathrm{S}}\right) /\left(\delta^{13} \mathrm{C}_{\mathrm{G}}-\delta^{13} \mathrm{C}_{\mathrm{L}}\right)$

where $\delta^{13} \mathrm{C}_{\mathrm{G}}$, $\delta^{13} \mathrm{C}_{\mathrm{L}}$ and $\delta^{13} \mathrm{C}_{\mathrm{S}}$ are the values of ${ }^{13} \mathrm{C}$ abundance of the faeces collected from animals fed on pure grass $\left({ }_{G}\right)$, pure legume $\left(_{\mathrm{L}}\right)$ and the diet being sampled $(\mathrm{S})$, respectively.

Calculation of faecal production from chromium oxide data - The steers were fed $6.84 \mathrm{~g}$ of $\mathrm{Cr}$ per day as $10 \mathrm{~g}$ of $\mathrm{Cr}_{2} \mathrm{O}_{3}$. From the concentration of $\mathrm{Cr}$ in the faeces $(\{\mathrm{Cr}\})$ determined colorimetrically, the daily faecal production (FP) was calculated from the formula:

$\mathrm{FP}=6.84 /\{\mathrm{Cr}\}$

If $\{\mathrm{Cr}\}$ is expressed in $\mathrm{mg} \mathrm{Cr} / \mathrm{g}$ then the resulting estimate of FP is in kg dry matter/day.

Calculation of forage intake from faecal production - The daily forage dry matter intake by the animals based on the in vitro digestibility was calculated by equation:

$\mathrm{DM}$ intake $=$ faecal production $/(1-(\% \mathrm{IVDDM} / 100))$

where $\%$ IVDDM is the $\%$ in vitro digestibility of dry matter.

Data were subjected to the tests of Lilliefors and Bartlett to evaluate the normality of the distribution of the data and homogeneity of the variances of the means, respectively, using the software MSTAT-C (Michigan State University). It was not necessary to transform data, as in all cases the data distributions was found to be not different from normal, and the variances of the means were found to be homogenous. The data were subsequently submitted to the parametric analysis of variance and models of regression were used to adjust the evaluated parameters for the five diets with five replicates considering $p=0.05$. This procedure was performed on the software SISVAR (Ferreira, 2008).

\section{Results and Discussion}

As expected, the legume was higher in total $\mathrm{N}$ content than in the grass (Table 1). There were no differences between the cellulose and fibre (ADF) contents of the feeds but lignin was higher in the $D$. ovalifolium compared to the grass and the grass was much higher in ash content than the legume.

When the data were expressed as $\mathrm{kg}$ intake per 100 $\mathrm{kg}$ animal live weight (LW), or as a function of the metabolic weight (LW $\mathrm{LW}^{0.75}$ - Crampton et al., 1960), the intake of forage increased linearly with decreasing legume content $(p<0.01)$. This legume is known to be of low pal- 
atability owing to its high tannin content (Cadisch et al., 1996). Only $25 \%$ of the grass in the mixture was sufficient to improve the palatability of the feed such that intake improved. This was evident when the uptake of crude protein $(\mathrm{N}$ content $\times 6.25)$ was examined. Although the crude protein (CP) content of the legume was considerably higher than that of the grass (11.4 versus $7.1 \%)$, increasing the proportion of legume in the diet above $75 \%$ of DM appeared to have little effect on the forage intake, although the trend analysis did not indicate a significant deviation from a linear relationship (Table 2)

The daily faecal production determined directly from the dry weight of faeces collected each day in the faecal collection bags was not significantly affected by the composition of the diets (Table 3). The faecal production was also determined indirectly from the analyses of chromium in the faecal samples taken in the last three days of each feeding period. The estimates derived from the use of this technique were, in general, similar. This is best assessed by comparing the recoveries of the daily dose of $10 \mathrm{~g}$ of chromium oxide administered to the animals (6.84 g Cr) (Table 3). Recoveries of $\mathrm{Cr}$ appeared to be higher at the afternoon sampling, but the mean daily recoveries ranged from 95.8 to 107.6 , this highest value being for the $100 \% \mathrm{D}$. ovalifolium diet. On average for all treatments, the mean recovery of $\mathrm{Cr}$ was $101 \%$.

Values of in vivo digestibility calculated from the ingested dry matter and the measured faecal production for all diets were close to 40 . The in vitro digestion of the forage mixtures yielded values of digestibility which ranged from 7 to $10 \%$ higher than the in vivo values and decreased with increasing legume content (Table 4). The correlation (in vivo $\mathrm{dg}=1.01$ [in vitro $\mathrm{dg}]+8.48$ ) between the in vivo and in vitro digestibility $(\mathrm{dg})$ was poor, yielding a coefficient of determination $\left(\mathrm{r}^{2}\right)$ of $0.57^{\text {ns }}$, but this rather low coefficient of regression was almost certainly due to the narrow range of the values of in vivo digestibility recorded for the different diets.

Few studies on the comparison between in vitro and in vivo studies for tropical forages are found in the literature. Holechek et al. (1986) studied Hereford $\times$ Angus yearling steers and found that the standard $48 \mathrm{~h}$ incubation procedure of Van Soest and Wine (1967) underestimated true in vivo digestibility of feeds ranging from only 1\% for sainfoin (Onobrychis viciae-folia), to 9\% for Timothy grass (Phleum pratense) and 13\% for silver

Table 1 - Chemical composition $\left(\mathrm{g} \mathrm{kg}^{-1}\right)$ of the experimental diets.

\begin{tabular}{lcccccc}
\hline Diet & Dry matter & Total N & ADF & Lignin & Cellulose & Ash \\
\hline $100 \%$ Bd & 904 & 11.5 & 396 & 68.6 & 278 & 34.8 \\
\hline $75 \%$ Bd : 25\% Do & 903 & 13.0 & 398 & 81.5 & 300 & 28.9 \\
$50 \%$ Bd : 50\% Do & 901 & 14.7 & 399 & 89.8 & 286 & 22.8 \\
$25 \%$ Bd : 75\% Do & 900 & 15.7 & 404 & 100.6 & 289 & 16.4 \\
$100 \%$ Do & 900 & 18.1 & 399 & 108.9 & 283 & 9.5 \\
\hline Coefficient of variation (\%) & 0.8 & 3.3 & 4.3 & 7.0 & 5.0 & 10.4 \\
\hline Regression Model & $\mathrm{ns}$ & $\mathrm{y}=0.06 \mathrm{x}+11.4$ & $\mathrm{~ns}$ & $\mathrm{y}=0.39 \mathrm{x}+69.9$ & $\mathrm{~ns}$ & $\mathrm{y}=-0.25 \mathrm{x}+35.1$ \\
\hline $\mathrm{r}^{2}$ & $\mathrm{~ns}$ & $0.99 * *$ & $\mathrm{~ns}$ & $0.99 * *$ & $\mathrm{~ns}$ & $0.99 * *$
\end{tabular}

$\mathrm{Bd}=$ Brachiaria dictyoneura. Do $=$ Desmodium ovalifolium. $\mathrm{ns}-$ means not different $(p<0.05) . *$ Regression model significant at $p<0.01$.

Table 2 - Intake of dry matter and crude protein of confined Zebu steers fed five diets containing mixtures of Desmodium ovalifolium (Do) and Brachiaria dictyoneura (Bd).

\begin{tabular}{|c|c|c|c|c|}
\hline Diet & DM intake & $\begin{array}{c}\text { Daily intake as a proportion of } \\
\text { live weight }\end{array}$ & $\begin{array}{l}\text { Daily intake as a proportion } \\
\text { of metabolic size }\end{array}$ & $\begin{array}{l}\text { Intake of crude } \\
\text { protein }^{\mathrm{B}}\end{array}$ \\
\hline & $\mathrm{kg} \mathrm{DM} \mathrm{day}^{-1}$ & \% & 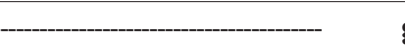 & $\mathrm{g} \mathrm{CP} \mathrm{day}^{-1}$ \\
\hline $100 \% \mathrm{Bd}$ & 6.67 & 2.25 & 7.27 & 476 \\
\hline $75 \% \mathrm{Bd} / 25 \%$ Do & 6.59 & 2.21 & 7.19 & 532 \\
\hline $50 \% \mathrm{Bd} / 50 \%$ Do & 6.31 & 2.14 & 7.07 & 579 \\
\hline $25 \% \mathrm{Bd} / 75 \% \mathrm{Do}$ & 6.49 & 2.19 & 7.17 & 634 \\
\hline $100 \%$ Do & 5.55 & 1.87 & 6.85 & 622 \\
\hline Coefficient of variation (\%) & 8.9 & 6.2 & 6.0 & 7.2 \\
\hline Regression Model & ns & $y=-0.003 x+2.29$ & $y=-0.008 x+7.67$ & $y=1.58 x+489.9$ \\
\hline $\mathrm{r}^{2}$ & ns & $0.66^{* * *}$ & $0.63 * *$ & $0.90 * \%$ \\
\hline
\end{tabular}

${ }^{\mathrm{A}}$ Metabolic size defined as (live weight) ${ }^{0.75}$ (Crampton et al., 1960). ${ }^{\mathrm{B}}$ Crude protein calculated as $\mathrm{N}$ content $\times 6.25$. ns - means not different $(p<0.05)$. $* *$ Regression model significant at $p<0.01$. 
Table 3 - In vivo faecal production determined by weighing faeces compared to estimates of faecal production determined from the chromium oxide technique (daily dose of $10 \mathrm{~g} \mathrm{Cr}_{2} \mathrm{O}_{3}$ ). Values are means of 15 data points ( 5 replicates $\times 3$ consecutive days).

\begin{tabular}{|c|c|c|c|c|}
\hline \multirow[t]{2}{*}{ Diet } & \multirow{2}{*}{$\begin{array}{l}\text { In vivo } \\
\text { Faecal production }\end{array}$} & \multicolumn{3}{|c|}{$\begin{array}{l}\text { Estimate of faecal production determined from } \mathrm{Cr}_{2} \mathrm{O}_{3} \text { technique and } \\
(\% \text { recovery of } \mathrm{Cr})^{\mathrm{A}}\end{array}$} \\
\hline & & Morning sample & Afternoon sample & Mean \\
\hline & $\mathrm{g} \mathrm{DM} \mathrm{day}^{-1}$ & 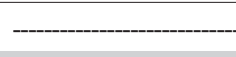 & _.____- & 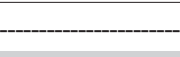 \\
\hline $100 \% \mathrm{Bd}^{\mathrm{B}}$ & 3741 & $3572(95.5)^{\mathrm{A}}$ & $3596(96.1)$ & $3584(95.8)$ \\
\hline $75 \% \mathrm{Bd} / 25 \% \mathrm{Do}^{\mathrm{C}}$ & 3230 & $3644(112.8)$ & $3378(104.6)$ & $3511(108.7)$ \\
\hline $50 \% \mathrm{Bd} / 50 \% \mathrm{Do}$ & 3489 & $3267(93.6)$ & $3422(98.1)$ & $3345(95.8)$ \\
\hline $25 \% \mathrm{Bd} / 75 \%$ Do & 3875 & $3729(96.2)$ & 3867 (99.8) & $3798(98.0)$ \\
\hline $100 \%$ Do & 3225 & $3338(103.5)$ & 3605 (111.8) & 3471 (107.6) \\
\hline Mean & 3512 & $3510(100.3)$ & $3574(102.0)$ & $3542(101.2)$ \\
\hline Coefficient of variation (\%) & $11.8 \mathrm{~ns}$ & $18.0 \mathrm{~ns}$ & $20.2 \mathrm{~ns}$ & $19.1 \mathrm{~ns}$ \\
\hline
\end{tabular}

${ }^{\mathrm{A}}$ Values in parentheses represent \% recovery of $\mathrm{Cr}=\left(100 \times\right.$ concentration of $\mathrm{Cr}$ in faecal sample $\left[\mathrm{g} \mathrm{kg}^{-1}\right] \mathrm{x}$ in vivo faecal production $[\mathrm{kg}]) / 6.84$. (NB: $10 \mathrm{~g}$ of $\mathrm{Cr}_{2} \mathrm{O}_{3}$ contains $6.84 \mathrm{~g} \mathrm{Cr}$ ). ${ }^{\mathrm{B}} \mathrm{Bd}=$ Brachiaria dictyoneura. ${ }^{\mathrm{C}} \mathrm{Do}=$ Desmodium ovalifolium. ns - not significant differences $(p<0.05)$.

Table 4 - In vivo and in vitro estimates of the OM digestibility of mixtures of B. dictyoneura (Bd) and D. ovalifolium (Do).

\begin{tabular}{|c|c|c|}
\hline Diet & "in vivo" digestibility & "in vitro" digestibility ${ }^{\mathrm{A}}$ \\
\hline & (- & 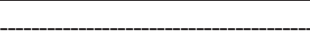 \\
\hline $100 \% \mathrm{Bd}$ & 47.7 & 58.1 \\
\hline $75 \% \mathrm{Bd} / 25 \% \mathrm{Do}$ & 46.2 & 53.5 \\
\hline $50 \% \mathrm{Bd} / 50 \% \mathrm{Do}$ & 47.3 & 54.9 \\
\hline $25 \% \mathrm{Bd} / 75 \% \mathrm{Do}$ & 40.3 & 50.2 \\
\hline $100 \%$ Do & 40.5 & 47.9 \\
\hline Mean & 44.4 & 52.9 \\
\hline Coefficient of variation (\%) & 8.7 & 6.8 \\
\hline Regression Model & $y=-0.08 x+48.4$ & $y=-0.09 x+57.6$ \\
\hline $\mathrm{r}^{2}$ & $0.76^{* * *}$ & $0.88^{* * \%}$ \\
\hline
\end{tabular}

${ }^{A}$ Determined by digestion in rumen liquor according to the technique of Tilley and Terry (1963). ns - not significant difference $(p<0.05)$. $* *$ Regression model significant at $p<0.01$.

blue stem (Bothriochloa saccharoides). Surprisingly, although there is a huge number of articles published in Portuguese regarding the digestibility of different feeds, it seems there are no reports available comparing in vitro and in vivo digestibilities of Brachiaria spp., or other important tropical forage grasses used in Brazil (e.g. Panicum maximum, Pennisetum purpureum). The fact that the in vitro estimates of digestibility (IVDDM) were higher than the in vivo estimates in this present study may be due to the low quality of the $B$. humidicola and $D$. ovalifolium hay, a problem mentioned by Van Soest (1994). For the purpose of utilising in vitro digestibility to estimate in vivo digestibility in the field, the regression equation in vivo $\mathrm{dg}=1.01$ (in vitro $\mathrm{dg}$ ) +8.48 could be used, although this would be specific for mixtures of these two species.

Lukas et al. (2005) used data from two digestibility trials, one in Germany with 257 individual comparisons (data set 1) and the other in Austria (188 comparisons, data set 2) to predict OM digestibility (y, \%) using a regression based on the crude protein content of the faeces $\left(\mathrm{x}, \mathrm{g} \mathrm{kg}^{-1}\right)$. The data were obtained from dairy and beef cattle confined in stalls with titanium oxide as an external indicator for faecal production. The best fit of the regression varied somewhat between data sets giving $\mathrm{y}=\mathrm{a}-107.7(\exp .(-0.01515 \times \mathrm{x}))$, where the value of 'a' for data set $1\left(a_{1}\right)$ was 79.76 and for data set $2\left(a_{2}\right)$ was 72.86 . Applying the data from the analyses of total CP in faeces (total $\mathrm{N} \times 6.25$ - Table 5) made for the last three days of each diet in our study, the estimates of $\mathrm{OM}$ digestibility from the regression increased from 50 to $58 \%$ using $a_{1}$, and from 43 to $51 \%$ using $\mathrm{a}_{2}$, when legume $(D$. ovalifolium) content of the diet increased from 0 to $100 \%$. However, both our in vivo and in vitro estimates of digestibility showed a linear decrease with increasing faecal CP content $(p<$ 0.01 ). This is almost certainly explained by the high tannin level in the legume (D. ovalifolium). Schlecht and Susenbeth (2006) used this same regression technique to estimate the digestibility of roughages from the Sahel 
Table 5 - Content of dry matter, nitrogen, acid detergent fibre (ADF), lignin, cellulose and ash insoluble in acid detergent (AIAD) in the faeces of animals fed with different proportions of legume in mixtures of $B$. dictyoneural D. ovalifolium.

\begin{tabular}{|c|c|c|c|c|c|c|}
\hline Diet & $\mathrm{DM}$ & Total N & $\mathrm{ADF}$ & Lignin & Cellulose & AIAD \\
\hline & - & 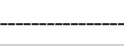 & - n l n & $\mathrm{g} \mathrm{kg}^{-1}$ & - n l & -5 \\
\hline $100 \% \mathrm{Bd}$ & 181 & 14.1 & 402 & $122(121)^{A}$ & 196 & $84.6(133)$ \\
\hline 75\% Bd: 25\%Do & 177 & 14.8 & 463 & $188(140)$ & 208 & $67.9(133)$ \\
\hline $50 \%$ Bd: $50 \% \mathrm{Do}$ & 183 & 17.0 & 499 & $237(162)$ & 210 & $52.5(137)$ \\
\hline 25\%Bd: $75 \% \mathrm{Do}$ & 180 & 16.8 & 535 & $246(166)$ & 246 & $41.3(147)$ \\
\hline $100 \%$ Do & 197 & 17.2 & 551 & $239(184)$ & 284 & $25.9(179)$ \\
\hline $\mathrm{CV}^{\mathrm{B}}(\%)$ & 9.8 & 14.9 & 1.6 & 12.2 & 11.9 & 7.1 \\
\hline Regression Model & ns & ns & $y=1.48 x+416.1$ & $y=-0.02 x^{2}+3.29 x+121.6 y$ & $y=0.85 x+186.1$ & $y=-0.58 x+83.2$ \\
\hline$r^{2}$ & ns & ns & $0.96 \%$ & $0.99 *$ & $0.88 \% *$ & $0.99 * *$ \\
\hline
\end{tabular}

${ }^{\mathrm{A}}$ Values in parentheses are apparent recovery (\%) of the component (lignin or AIAD) in the faeces compared to the intake of the same component. ${ }^{\mathrm{B}} \mathrm{CV}-$ Coefficient of variation. ns - means not different $(p<0.05)$. **Regression model significant at $p<0.01$.

region of Africa and stated that if anti-nutritional dietary factors increase the concentration of faecal nitrogen, the approach might considerably overestimate dietary digestibility.

Fibre, lignin and cellulose contents all increased in the faeces with increasing content of the $D$. ovalifolium in the diet, but the ash content decreased (Table 5). This was also true for the original samples of the diets, with exception of the fibre (ADF) and cellulose, where there was no appreciable difference between the forage mixtures. This indicates that the fibre in the diets was more difficult to digest when the legume content was high. If the animals are unable to digest either the lignin or ash, then these parameters could in theory be used as internal indicators to determine the digestibility.

Recoveries of both components using the in vivo digestibility were over $100 \%$ (Table 5). In the case of the ash content this was to be expected as the animals had access to mineral salt ad libitum and they consumed approximately $100 \mathrm{~g} \mathrm{day}^{-1}$ (exact quantities not recorded). The apparent recovery of lignin ranged from 20 to $84 \%$ higher than that registered in the original feed, and this value increased with the proportion of D. ovalifolium in the diet. This apparent net gain in lignin through the digestive tract has been previously reported by several authors (Allinson and Osbourn, 1997; Norton and Ahn, 1997) and can be explained by the complexing of polyphenols to form tannin-carbohydrate and tannin-protein complexes, which are quantified by the analytical method used (Van Soest and Wine, 1967) as lignin.

In this study no internal markers were found to be suitable for the prediction of animal consumption. While ash (for example; ash insoluble in acid detergent - AIAD) may be almost totally indigestible, such an indicator would be useless in the field on extensive Brachiaria-based pastures, or with the low quality diet provided in this study, as it is essential to allow the animals access to extra mineral salts, especially as a source of $\mathrm{P}$. This meant that the use of an external marker would be the only feasible technique to estimate herbage intake by animals in the field. The chromic oxide technique (Raymond and Minson, 1955) has long been used and has the advantage that the materials necessary are inexpensive and the analysis for $\mathrm{Cr}$ can be made either colorimetrically, as was the case in this study, or by atomic absorption spectroscopy. The use of the ratio of inherent herbage and added $n$ alkanes offers several advantages for estimating herbage intake (Mayes et al., 1986) but most laboratories in developing countries (including ours) do not possess a suitably equipped gas chromatograph to analyse the nalkanes to apply this technique.

Even though the chromic oxide was fed directly to the animals as powder, and not impregnated in plant material or other absorbent (Burns et al., 1994), the faecal production as calculated from the concentration of chromium in the faecal samples was generally in good agreement with the measurements in vivo (Table 3). The coefficient of variation associated with the estimates ranged from 18 to $20 \%$, considerably higher than that associated with the in vivo technique $(11.8 \%)$, suggesting that considerable replication (several animals) should be used for each evaluation.

The ${ }^{13} \mathrm{C}$ abundance of the Brachiaria dictyoneura hay was $-12.1 \%$, typical of this tropical grass species with a $\mathrm{C}_{4}$ photosynthetic pathway (Jones and Lascano, 1992; Cantarutti et al., 2002), and that of the D. ovalifolium was $-26.6 \%$, typical for this $\mathrm{C}_{3}$ species (Cantarutti et al., 2002). The $\delta^{13} \mathrm{C}$ value of the $D$. ovalifolium hay was $-26.6 \%$, which was intermediate between the values of -27.5 and $-25.3 \%$ for forage on offer and litter of this legume determined by Cantarutti et al. (2002) from samples taken from this same site. Carbon concentrations in the $B$. dictyoneura and the D. ovalifolium were, respectively, $399 \pm 1$ and $410 \pm 5 \mathrm{~g} \mathrm{~kg}^{-1}$ (means of five analyses on the mass spectrometer). Using the ${ }^{13} \mathrm{C}$ abun- 
dance measured for the different legume/grass mixtures to calculate the proportions of legume $\mathrm{C}$ in the mixtures using Eq. 1 yielded values of 23.4, 47.4 and 70.3 for the mixtures containing 25, 50 and $75 \%$ legume, which when expressed on a dry matter basis became $22.9,46.7$ and $69.7 \%$ legume.

Six days after the change from one diet to another, the ${ }^{13} \mathrm{C}$ abundance was essentially stable even when the diet changed from $100 \%$ grass to $100 \%$ legume (Figure 1). The ${ }^{13} \mathrm{C}$ abundance of the faeces was between 1.6 and $2.1 \%$ more negative than that of the fed ration except

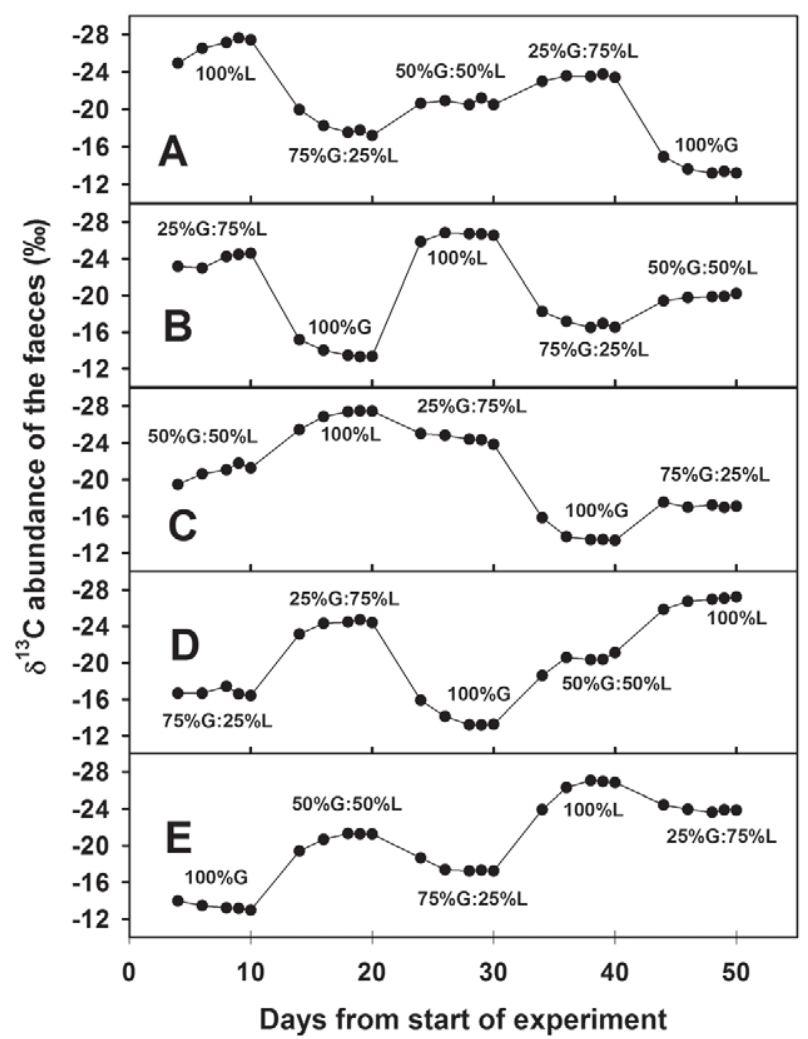

Figure 1 - Variation in ${ }^{13} \mathrm{C}$ natural abundance delta values of feaces from Zebu steers fed with five mixtures of the legume (L) D. ovalifolium and the grass $(\mathrm{G}) B$. bumidicola for five consecutive periods of ten days. Data points are for 4, 6, 8, 9 and 10 days after change of ration. for the pure legume diet for which there was no detectable difference (Table 6). The concentration of $\mathrm{C}$ in the faeces collected from animals fed on $100 \%$ grass and $100 \%$ legume were, respectively, $378 \pm 6$ and $396 \pm 5 \mathrm{~g}$ $\mathrm{kg}^{-1}$. The indigestible fraction of the forages seems to have lower $\mathrm{C}$ concentration than in the original hay. The regression of the ${ }^{13} \mathrm{C}$ abundance of the faeces with that of the diet (means of the last three days of feeding in each 10 day period) was well fitted to a linear equation $\left(\delta^{13} \mathrm{C}\right.$ faeces $=0.947 \cdot\left[\delta^{13} \mathrm{C}\right.$ diet $\left.]-2.49\right)\left(r^{2}=0.97\right.$ - Figure 2). When transformed into a regression of $\%$ legume in the diet with ${ }^{13} \mathrm{C}$ abundance of the faeces (\% legume in diet $=-7.158\left[\delta^{13} \mathrm{C}\right.$ faeces $\left.]-96.56\right)$ the coefficient of determination was even higher $\left(\mathrm{r}^{2}=0.99\right)$. The prediction of the $\%$ legume in the $D$. ovalifolium/B. dictyoneura mixtures were, respectively, 1.5, 27.2, 50.2, 75.2 and $95.8 \%$, in the diets containing $0,25,50,75$ and $100 \% D$. ovalifolium.

For the faeces of animals fed any of the diets containing grass (25 to $100 \%$ ), the ${ }^{13} \mathrm{C}$ abundance was between 1.66 and $2.07 \%$ higher (less negative) than in the ration. Similar results, but generally with smaller differences were obtained by various authors (Jones et al., 1979; Jones, 1981; Coates et al., 1991). The reason for this

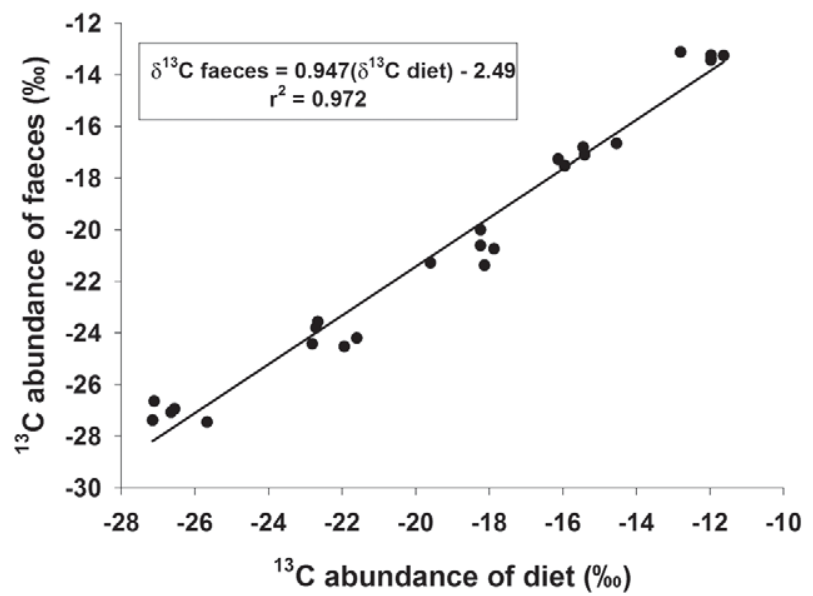

Figure 2 - Regression of ${ }^{13} \mathrm{C}$ natural abundance delta values of feaces of Zebu steers, and of the five different rations fed to the cattle. Data points are the values for the five rations for the five steers in the experiment.

Table $6-{ }^{13} \mathrm{C}$ natural abundance delta values of the diets containing proportions of $B$. dictyoneura $(\mathrm{Bd})$ and $D$. ovalifolium (Do) and the faeces excreted by the steers fed with these diets. Values of $\delta^{13} \mathrm{C}$ for the diets are means of five replicates and the values for the faeces are means of the last three days of feeding with each diet and five replicates per sample.

\begin{tabular}{lccc}
\hline Treatment & $\delta^{13} \mathrm{C}$ diet & $\delta^{13} \mathrm{C}$ Faeces & Difference \\
\hline 100\%Bd & $-12.1 \pm 0.6$ & $-13.7 \pm 0.8$ & -1.69 \\
\hline $75 \%$ Bd:25\%Do & $-15.5 \pm 0.8$ & $-17.3 \pm 0.8$ & -1.85 \\
$50 \%$ Bd:50\%Do & $-18.4 \pm 1.2$ & $-20.5 \pm 0.7$ & -2.07 \\
$25 \%$ Bd:75\%Do & $-22.3 \pm 1.1$ & $-24.0 \pm 0.6$ & -1.66 \\
$100 \%$ Do & $-26.6 \pm 0.7$ & $-26.6 \pm 0.9$ & -0.01 \\
\hline
\end{tabular}


lower ${ }^{13} \mathrm{C}$ abundance in the faeces does not appear to have been investigated, and Jones (1981) suggested that some isotope discrimination might occur in the gut via microorganisms or through gaseous losses during digestion. In the case of the pure legume $(D$. ovalifolium $)$ diet, the $\delta^{13} \mathrm{C}$ of the faeces was almost identical to that of the feed.

The mean live weight gain (LWG) of the animals was $350 \mathrm{~g} \mathrm{day}^{-1}$ during the experiment. If it is assumed that the total $\mathrm{N}$ in the animal carcass is $2.5 \%$ of the live weight (Scholefield et al., 1991) then the total N gained by the animals each day should be $8.8 \mathrm{~g} / \mathrm{head} /$ day. So the total $\mathrm{N}$ excreted in urine should be the difference between the $\mathrm{N}$ consumed and the $\mathrm{N}$ excreted as faeces and that accumulated in the LWG (Berry et al., 2002). When working in the field situation it is possible using external markers to estimate faecal production, and if the digestibility of the acquired forage can be measured, or estimated, then total dry matter intake can be calculated. If the $\mathrm{N}$ content of the acquired ration and the faeces is known it is possible to estimate $\mathrm{N}$ intake and $\mathrm{N}$ excreted in the faeces. However, it is virtually impossible to collect all urine from free grazing animals, especially animals such as Zebu steers which are far from docile. It therefore becomes interesting to estimate urine $\mathrm{N}$ from the consumed $\mathrm{N}$ and the $\mathrm{N}$ excreted as faeces (Table 7). As most $\mathrm{N}$ losses in the field result from urine patches it is most useful to be able to evaluate total $\mathrm{N}$ excreted in urine. Estimating urine production from grazing animals is extremely difficult, but if total forage consumption and the digestibility and concentration of $\mathrm{N}$ of this forage can be measured or estimated, then this ratio can used to calculate total $\mathrm{N}$ excreted in urine. Scholefield et al. (1991) determined that the ratio $\left(\mathrm{R}_{\mathrm{u} / \mathrm{f}}\right)$ of $\mathrm{N}$ excreted in urine to that excreted could be described by the formula: $R_{u / f}=[1.2725 \%(\% \mathrm{~N}$ in diet $)]-1.09$.

The relationship presented by Scholefield et al. (1991) did not show a very close relationship to the re- sults obtained in this study (Table 7). This is not surprising as the data used for Scholefield's model were obtained from ryegrass, clover and other temperate forages, considerably higher in $\mathrm{N}$ content than the $B$. dictyoneura hay $\left(11.4 \mathrm{gN} \mathrm{kg} \mathrm{DM}^{-1}\right)$ and that the high content of polyphenols of the $D$. ovalifolium, unusual in temperate forages, which immobilise protein in the rumen such that it is excreted in the faeces rather than being assimilated. This latter effect was apparent when the legume content in the diet increased from 25 to $50 \%$, the concentration of $\mathrm{N}$ in the faeces increased from 14.8 to 17.0 $\mathrm{gN} \mathrm{kgDM}^{-1}$ (Table 5). While the linear regression model of Scholefield et al. (1991) indicated that dietary $\mathrm{N}$ concentration increasing from 14.4 to $18.2 \mathrm{~g} \mathrm{~N} \mathrm{~kg} \mathrm{DM}^{-1}$ when the legume content increased from 50 to $100 \%$, the ratio of urine $\mathrm{N}$ to faecal $\mathrm{N}\left(\mathrm{R}_{\mathrm{u} / \mathrm{f}}\right)$, should increase from 0.74 to 1.22 , but for this forage legume/Brachiaria mixture the $\mathrm{R}_{\mathrm{u} / \mathrm{f}}$ increased from only 0.54 to 0.83 (Table 7).

\section{Conclusions}

Neither ash insoluble in acid detergent (AIAD) nor lignin was useful as internal markers for the evaluation of faecal production. However, the use of chromic oxide as an external marker was satisfactory in all cases, and resulted in estimates of within $10 \%$ of the true value. The proportion of legume in the diet can be reliably predicted from the analysis of ${ }^{13} \mathrm{C}$ abundance of the faeces.

\section{Acknowledgements}

To the "Fundação Banco do Brasil" (Project No. 10/ 04296-XI), Embrapa and research grants "Cientista de Nosso Estado" (FAPERJ), and to CNPq. Acknowledgments are given to Roberto G. de Souza, Altiberto M. Baêta, José Vincente Alves and Roberto Andrade and to thank Dr. Phillip Chalk for reading and correcting the text.

Table 7 - Forage dry matter (DM) and $\mathrm{N}$ intake, output in faeces and estimates of $\mathrm{N}$ excreted in urine by Zebu steers fed on diets ranging from 100\% Brachiaria dictyoneura (Bd) to 100\% Desmodium ovalifolium (Do). Daily forage intake estimated directly from weight of ration consumed, and faecal production measured from complete collection of faeces.

\begin{tabular}{|c|c|c|c|c|c|c|c|}
\hline Diet composition & $\begin{array}{l}\text { Forage } \\
\text { intake }\end{array}$ & $\begin{array}{c}\text { In vivo Faecal } \\
\text { prod }\end{array}$ & Total $\mathrm{N}$ diet & $\begin{array}{c}\text { Total N } \\
\text { faeces }\end{array}$ & $\begin{array}{c}\text { Total N } \\
\text { excreted in urine }\end{array}$ & $\begin{array}{l}\text { Ratio Urine } \\
\text { N:Faecal N }\end{array}$ & $\begin{array}{c}\text { Scholefield }^{\mathrm{B}} \\
\text { Ratio }\end{array}$ \\
\hline & \multicolumn{2}{|c|}{ kg DM day ${ }^{-1}$} & 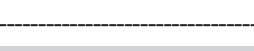 & $\mathrm{N}_{\text {day }}{ }^{-1}$ & & & $\left(R_{u / f}\right)$ \\
\hline $100 \% \mathrm{Bd}$ & 6.67 & 3.74 & 76.2 & 52.2 & 15.2 & 0.291 & 0.361 \\
\hline $75 \%$ Bd: $25 \%$ Do & 6.59 & 3.23 & 85.2 & 56.2 & 20.1 & 0.358 & 0.564 \\
\hline 50\%Bd:50\%Do & 6.31 & 3.49 & 92.6 & 58.7 & 25.2 & 0.429 & 0.742 \\
\hline 25\%Bd: $75 \%$ Do & 6.49 & 3.88 & 101.5 & 64.7 & 27.6 & 0.427 & 0.908 \\
\hline $100 \%$ Do & 5.55 & 3.23 & 99.5 & 55.3 & 35.4 & 0.640 & 1.226 \\
\hline $\mathrm{CV}^{\mathrm{C}}(\%)$ & 8.9 & 11.8 & 13.3 & 19.2 & 43.1 & - & - \\
\hline Regression Model & ns & ns & $y=0.25 x+78.4$ & ns & ns & - & - \\
\hline $\mathrm{r}^{2}$ & ns & ns & $0.90 \% *$ & ns & ns & - & \\
\hline
\end{tabular}

${ }^{\mathrm{A}} \mathrm{N}$ excreted in urine estimated from Total $\mathrm{N}$ intake - Total N excreted in faeces - Total N in LWG $\left(8.8 \mathrm{~g}\right.$ head day $\left.{ }^{-1}\right) .{ }^{\mathrm{B}} \mathrm{Based}$ on the formula published by Scholefield et al. (1991): $\mathrm{R}_{\mathrm{u} / \mathrm{f}}=[1.2725 *(\% \mathrm{~N}$ in diet $)]-1.09 .{ }^{\mathrm{C}} \mathrm{CV}$ - Coefficient of variation. 


\section{References}

Allinson, D.W.; Osbourn, D.F. 1997. The cellulose-lignin complex in forages and its relationship to forage nutritive value. Journal of Agricultural Science 74: 23-36.

Arnold, S.L.; Schepers, J.S. 2004. A simple roller-mill grinding procedure for plant and soil samples. Communications in Soil Science and Plant Analysis 35: 537-545.

Berry, N.R.; Jewell, P.L.; Sutter, F.; Edwards, P.J.; Kreuzer, M. 2002. Selection, intake and excretion of nutrients by Scottish Highland suckler beef cows and calves, and Brown Swiss dairy cows in contrasting Alpine grazing systems. Journal of Agricultural Science 139: 437-453.

Boddey, R.M.; Macedo, R.; Tarré, R.M.; Ferreira, E.; De Oliveira, O.C.; Rezende, C.P.; Cantarutti, R.B.; Pereira, J.M.; Alves, B.J.R.; Urquiaga, S. 2004. Nitrogen cycling in Brachiaria pastures: the key to understanding the process of pasture decline. Agriculture, Ecosystems and Environment 103: 389-403.

Burns, J.C.; Pond, K.R.; Fisher, D.S. 1994. Measurement of forage intake. p. 494-532. In: Fahey Jr., G.C., ed. Forage Quality, Evaluation and Utilization. American Society of Agronomy, Madison, WI, USA.

Cadisch, G.; Imhof, H.; Urquiaga, S.; Boddey, R.M.; Giller, K.E. 1996. Carbon turnover $\left(\delta^{13} \mathrm{C}\right)$ and nitrogen mineralization potential of particulate light soil organic matter after rainforest clearing. Soil Biology and Biochemistry 28: 1555-1567.

Cantarutti, R.B.; Tarré, R.M.; Macedo, R.; Cadisch, G.; Rezende, C.D.P.; Pereira, J.M.; Braga, J.M.; Gomide, J.A.; Ferreira, E.; Alves, B.J.R.; Urquiaga, S.; Boddey, R.M. 2002. The effect of grazing intensity and the presence of a forage legume on nitrogen dynamics in Brachiaria pastures in the Atlantic forest region of the South of Bahia, Brazil. Nutrient Cycling in Agroecosystems 64: 257-271.

Coates, D.B.; Schachenmann, P.; Jones R.J. 1987. Reliability of extrusa samples collected from steers fistulated at the oesophagus to estimate the diet of resident animals in grazing experiments. Australian Journal of Experimental Agriculture 27: 739-745.

Coates, D.B.; Van der Weide, A.P.A.; Kerr J.D. 1991. Changes in faecal $\delta^{13} \mathrm{C}$ in response to changing proportions of legume $\left(\mathrm{C}_{3}\right)$ and grass $\left(\mathrm{C}_{4}\right)$ in the diet of sheep and cattle. Journal of Agricultural Science 116: 287-295.

Cochran, R.C.; Adams, D.C.; Wallace, J.D. 1986. Predictive digestibility of different diets with internal markers. Journal of Animal Science 63: 1476-1483.

Crampton, E.W.; Donefer, E.; Lloyd, L.E. 1960. A nutritive value index for forages. Journal of Animal Science 19: 538-544.

Empresa Brasileira de Pesquisa Agropecuária [EMBRAPA]. 2007. Cultivation and use of Stylosanthes cv. Embrapa-CNPGC, Campo Grande, MS, Brazil. 11p. (Technical Communication, 105). Available at: http://www.cnpgc.embrapa.br/publicacoes/ cot/pdf/Cot105.pdf. [Accessed Apr. 05, 2010]. (in Portuguese).

Ferreira, D.F. 2008. SISVAR: um programa para análises e ensino de estatística. Symposium 6(2): 36-41.

Holechek, J.L.; Wofford, H.; Arthun, D.; Galyean, M.L.; Wallace, J.D. 1986. Evaluation of total fecal collection for measuring cattle forage intake. Journal of Range Management 39: 2-4.

Jones, R.J. 1981. The use of natural carbon isotope ratios in studies with grazing animals. p. 227-285. In: Wheeler, J.L.; Mochrie, R.D., eds. Forage evaluation: concepts and techniques. CSIRO: Armidale, New South Wales, Australia.

Jones, R.J.; Lascano, C.E. 1992. Oesophageal fistulated cattle can give unreliable estimates of the proportion of legume in the diets of resident animals grazing tropical pastures. Grass and Forage Science 47: 128-132.

Jones, R.J.; Ludlow, M.M.; Troughton, J.H.; Blunt, C.G. 1979. Estimation of the proportion of $\mathrm{C}_{3}$ and $\mathrm{C}_{4}$ plant species in the diet of animals from the ratio of natural ${ }^{12} \mathrm{C}$ and ${ }^{13} \mathrm{C}$ isotopes in the faeces. Journal of Agricultural Science 92: 91-100.
Kimura, F.T.; Miller, V.L. 1956. Improved determination of chromic oxide in cow feed and feces. Agriculture and Food Chemistry 5: 216.

Lukas, M; Südekum, K.-H.; Rave, G.; Friedel, K.; Susenbeth, A. 2005. Relationship between fecal crude protein concentration and diet organic matter in cattle. Journal of Animal Science 83: 1332-1344.

Malossini, F.; Bovolenta, S.; Piasentier, E.; Piras, C.; Martillotti, F. 1996. Comparison of n-alkanes and chromium oxide methods for determining herbage intake by grazing dairy cows. Animal Feed Science and Technology 61: 155-165.

Mayes, R.W.; Lamb, C.S.; Colgrove, P.M. 1986. The use of dosed and herbage $n$-alkanes as markers for the determination of herbage intake. Journal of Agricultural Science 107: 161-170.

Norton, B.W.; Ahn, J.H. 1997. A comparison of fresh and dried Calliandra calothyrsus supplements for sheep giving a basal diet of barley straw. Journal of Agricultural Science 129: 485-494.

Oliveira, D.E.; Medeiros, S.R.; Tedeschi, L.O.; Aroeira, L.J.M.; Da Silva, S.C. 2007. Estimating forage intake of lactating dualpurpose cows using chromium oxide and $\mathrm{N}$-alkanes as external markers. Scientia Agricola 64: 103-110.

Pereira, J.M.; Rezende, C.P.; Moreno, M.A.R. 2005. Pastures in the Atlantic Forest ecosystem: present situation and perspectives. p. 36-55. In: Proceedings of the Annual Meeting of the Brazilian Society of Animal Sciences. SBZ, Brasília, DF, Brazil.

Raymond, W.F.; Minson, D.J. 1955. The use of chromic oxide for estimating the faecal production of grazing animals. Journal of the British Grassland Society 10: 282-296.

Rezende, C.P.; Cantarutti, R.B.; Braga, J.M.; Gomide, J.A.; Pereira, J.M.; Ferreira, E.; Tarré, R.M.; Macedo, R.; Alves, B.J.R.; Urquiaga, S.; Cadisch, G.; Giller, K.E.; Boddey, R.M. 1999. Litter deposition and disappearance in Brachiaria pastures in the Atlantic forest region of the South of Bahia, Brazil. Nutrient Cycling in Agroecosystems, 54: 99-112.

Russelle, M.P. 1997. Nutrient cycling in pasture. p. 235-266. In: Gomide, J.A., ed. Proceedings of the International Symposium on Animal Production under Grazing. Universidade Federal de Viçosa, Viçosa, MG, Brazil.

Scholefield, D.; Lockyer, D.R.; Whitehead, D.C.; Tyson, C. 1991. A model to predict transformations and losses of nitrogen in UK pastures grazed by beef cattle. Plant and Soil 132: 165-177.

Schlecht, E.; Susenbeth, A. 2006. Estimating the digestibility of Sahelian roughages from faecal crude protein concentration of cattle and small ruminants. Journal of Animal Physiology and Animal Nutrition 90: 369-379.

Tilley, J.M.; Terry, R.A. 1963. A two stage technique for the "in vitro" digestion of forage crops. Journal of the British Grassland Society 18: 104-111.

Urquiaga, S.; Cruz, K.H.S.; Boddey, R.M. 1992. Contribution of nitrogen fixation to sugar cane: Nitrogen-15 and nitrogen-balance estimates. Soil Science Society of America Journal 56: 105-114.

Valentim, J.F.; Carneiro, J.C.; Sales, M.F.L. 2001. Forage groundnut cv. Belmonte: a legume for the diversification of pastures and conservatiuon of soil in Acre. Circular Técnica 43, EmbrapaCPAFAC, Rio Branco, AC, Brazil. (in Portuguese).

Van Soest, P.J.; Wine, R.M. 1967. Use of detergents in the analysis of fibrous feeds. IV. The determination of plant cell wall constituents. Journal of the Association of Official Analysis Chemists 50: 50-55.

Van Soest, P.J. 1994. Nutritional Ecology of the Ruminant. Cornell University, Ithaca, NY, USA.

Received June 12, 2008

Accepted March 22, 2010 